\title{
Seasonal cycle and source analyses of aerosol optical properties in a semi-urban environment at Puijo station in Eastern Finland
}

\author{
A. Leskinen ${ }^{1}$, A. Arola ${ }^{1}$, M. Komppula ${ }^{1}$, H. Portin ${ }^{1,2}$, P. Tiitta ${ }^{2,3^{*}}$, P. Miettinen ${ }^{2}$, S. Romakkaniemi ${ }^{2}$, A. Laaksonen ${ }^{2,4}$, \\ and K. E. J. Lehtinen ${ }^{1,2}$ \\ ${ }^{1}$ Finnish Meteorological Institute, Kuopio, Finland \\ ${ }^{2}$ Department of Applied Physics, University of Eastern Finland, Kuopio, Finland \\ ${ }^{3}$ Atmospheric Chemistry Research Group, North-West University, Potchefstroom, South Africa \\ ${ }^{4}$ Finnish Meteorological Institute, Helsinki, Finland \\ * present address: Fine Particle and Aerosol Laboratory, University of Eastern Finland, Kuopio, Finland
}

Correspondence to: A. Leskinen (ari.leskinen@fmi.fi)

Received: 27 October 2011 - Published in Atmos. Chem. Phys. Discuss.: 10 February 2012

Revised: 28 May 2012 - Accepted: 10 June 2012 - Published: 28 June 2012

\begin{abstract}
We introduce a four-year (in 2006-2010) continuous data set of aerosol optical properties at Puijo in Kuopio, Finland. We study the annual and diurnal variation of the aerosol scattering and absorption coefficients, hemispheric backscattering fraction, scattering Ångström exponent, and single scattering albedo, whose median values over this period were $7.2 \mathrm{Mm}^{-1}$ (at $550 \mathrm{~nm}$ ), $1.0 \mathrm{Mm}^{-1}$ (at $637 \mathrm{~nm}$ ), $0.15,1.93$ (between 450 and $550 \mathrm{~nm}$ ), and 0.85 , respectively. The scattering coefficient peaked in the spring and autumn, being 2-4 times those in the summer and winter. An exception was the summer of 2010, when the scattering coefficient was elevated to $\sim 300 \mathrm{Mm}^{-1}$ by plumes from forest fires in Russia. The absorption coefficient peaked in the winter when soot-containing particles derived from biomass burning were present. The higher relative absorption coefficients resulted in lower single scattering albedo in winter. The optical properties varied also with wind direction and time of the day, indicating the effect of the local pollutant sources and the age of the particles. Peak values in the single scattering albedo were observed when the wind blew from a paper mill and from the sector without local pollutant sources. These observations were linked, respectively, to the sulphaterich aerosol from the paper mill and the oxygenated organics in the aged aerosol, which both are known to increase the scattering characteristics of aerosols. Decreases in the single scattering albedo in the morning and afternoon, distinct in the summertime, were linked to the increased traffic density at these hours. The scattering and absorption coefficients of
\end{abstract}

residential and long-range transported aerosol (two separate cloud events) were found to be decreased by clouds. The effect was stronger for the scattering than absorption, indicating preferential activation of the more hygroscopic aerosol with higher scattering characteristics.

\section{Introduction}

According to the Intergovernmental Panel on Climate Change the direct effect of aerosols to radiative forcing is still highly uncertain (IPCC, 2007). The direct effect arises from light extinction by aerosol particles, i.e. due to the combined effect of aerosol light scattering and absorption. Evaluation of the direct effect's magnitude is complicated, because these properties depend on the wavelength of the incident light and the angular distribution of the scattered light, which, in turn, depends, e.g., on the size, concentration, and chemical composition of the aerosol particles. Particles that contain sulfate, nitrate, and organic carbon predominately scatter light, and particles that contain black carbon absorb it. Furthermore, internal mixing (e.g., of organics and black carbon) may dramatically influence the aerosol optical properties (Shiraiwa et al., 2010).

The optical properties of aerosol particles are usually retrieved from remote sensing instruments, such as Lidar (Klett, 1981; Ansmann et al., 1990), or from in situ instruments, either airborne (e.g., Shinozuka et al., 2011; Chen et

Published by Copernicus Publications on behalf of the European Geosciences Union. 
al., 2011) or ground-based (e.g., Bodhaine, 1983; Bodhaine, 1995; Virkkula et al., 2011). The extinction can be measured, e.g., with a pulsed cavity ring-down spectrometer (Baynard et al., 2007), scattering with nephelometers (Heintzenberg et al., 1996; Anderson et al., 1996), and absorption with photometers (Arnott et al., 1999; Petzold and Schönlinner 2004). Other important intensive properties, such as the single scattering albedo (SSA), can be derived from the measured values. The SSA can be used to determine whether an aerosol layer causes net heating or cooling. If multi-wavelength instruments are used, Ångström exponents can be derived for scattering $\left(\stackrel{\circ}{\mathrm{s}}_{\mathrm{s}}\right)$ and absorption $\left(\stackrel{\circ}{a}_{\mathrm{a}}\right)$. The Ångström exponents depend inversely on the size of the aerosol particles: A small exponent indicates large aerosol particles, such as sea salt and dust, whereas a large exponent is connected to smaller aerosol particles (Bohren and Huffman, 1983), originating, for example, from combustion processes. However, one should be careful, because the $\stackrel{\circ}{\mathrm{s}}_{\mathrm{s}}$ also depends on the imaginary part of the refractive index, especially for highly absorbing aerosol (Bond et al., 2009).

Measurements of aerosol optical properties have been conducted worldwide. Long-term and campaign-wise measurements have been carried out to study climatologies at multiples sites (e.g., Bodhaine, 1983, 1995; Delene and Ogren, 2002; Andrews et al., 2011) as well as for a single site (e.g., Aaltonen et al., 2006; Hyvärinen et al., 2009; Collaud Coen et al, 2011; Virkkula et al., 2011). The advantage of focusing on measurements at a single site is that it allows for more in-depth exploration of, e.g., what causes temporal cycles. In most studies, particle size and concentration have been coupled to the aerosol optical properties, but, for example, the chemical composition and the optical properties of aerosols have been analyzed in parallel only in few studies.

In this study we introduce a previously unpublished fouryear data set of aerosol optical properties and meteorological parameters measured at a semi-urban measurement station, $230 \mathrm{~m}$ above the surroundings, in an observation tower at Puijo in Kuopio, Finland (Leskinen et al., 2009). We interpret the annual and diurnal variation of the aerosol scattering and absorption coefficients, single scattering albedo, scattering Ångström exponent and hemispheric backscattering fraction. We classify the optical properties, as well as aerosol chemical composition obtained from aerosol mass spectrometry, according to the wind direction in order to inspect the effect of the local sources. Finally, we examine how the scattering and absorption coefficients behave before, during, and after a cloud event, i.e. a time period when the station was covered by clouds.

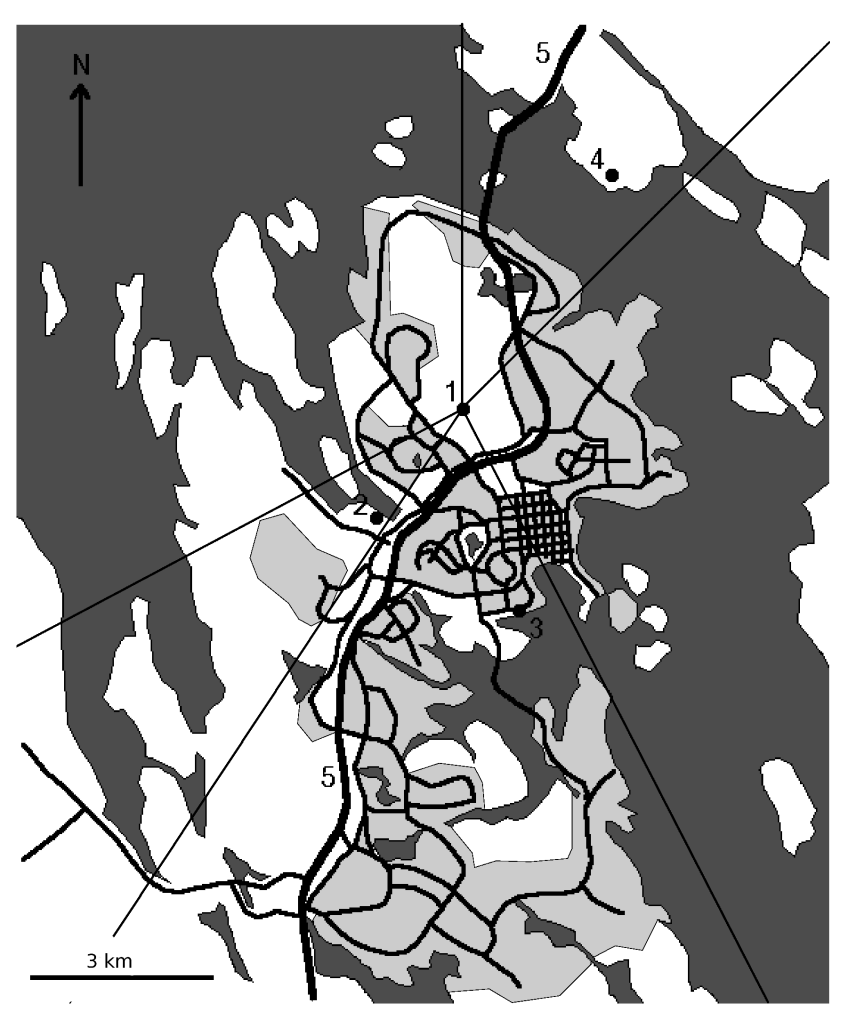

Fig. 1. Map of Kuopio showing Puijo (1) and its surroundings. The dark grey areas are lakes, the light grey areas residential areas, and the white areas forest. Also shown are the location of Savilahti measurement station (2), a peat-fired district heating plant (3), a paper mill (4), and a highway (5). The lines emerging from Puijo define sectors for local source analysis. The direction of North and a distance bar of $3 \mathrm{~km}$ are also shown in the figure.

\section{Methods}

\subsection{Site description}

The measurement station at Puijo $\left(62^{\circ} 54^{\prime} 34^{\prime \prime} \mathrm{N}\right.$, $27^{\circ} 39^{\prime} 19^{\prime \prime} \mathrm{E}$ ) is on the top of an observation and retransmitting tower, which is a $75 \mathrm{~m}$ high building on the Puijo hill (elevation $150 \mathrm{~m}$ ), approximately $2 \mathrm{~km}$ northwest of the city center of Kuopio (population 97000). The measurements are carried out at the height of $306 \mathrm{~m}$ a.s.l. and $224 \mathrm{~m}$ above the surrounding lake level. Puijo hill is in the southern boreal climatic zone and the surroundings is characterized by forests with conifer (mostly pine and spruce) and deciduous (mostly birch) trees, an undulating terrain with rocky soil and moderate hills and many lakes (Fig. 1).

We categorize the Puijo measurement station as a semiurban measurement station, because there are local pollutant sources (traffic routes, residential areas, industrial plants) in a particular sector $\left(0-245^{\circ}\right)$ seen from the Puijo tower, whereas the remaining sector $\left(245-360^{\circ}\right)$ represents a "cleaner" sector with almost no local sources. This enables studying 
the effects of fresh emissions on various aerosol properties (Leskinen et al., 2009). Furthermore, its elevated location enables studies of the interaction of aerosols with low-level clouds (Portin et al., 2009).

Since its establishment in 2005 by the research groups at the Finnish Meteorological Institute in Kuopio and Helsinki and at the University of Eastern Finland (Kuopio), we have instrumented the station for continuous measurements of aerosols, cloud droplets, weather parameters and trace gases. In 2009, the Puijo measurement station became a part of the Station for Measuring Forest Ecosystem - Atmosphere Relations network as its fourth member (SMEAR IV). More details about the measurement station and an overview of the activities in its early stages are given in Leskinen et al. (2009) and Portin et al. (2009).

\subsection{Instrumentation}

We measured the meteorological parameters (temperature, relative humidity, atmospheric pressure, horizontal wind speed and direction, visibility and precipitation intensity and type) on the roof of the Puijo tower with a time resolution of 1 min. The temperature and relative humidity transmitters, and the ultrasonic wind anemometer (Thies UA2D) are $2 \mathrm{~m}$ and $5 \mathrm{~m}$ above the roof, respectively. The present weather sensor (Vaisala FD12P) and a weather camera, facing northwards, are attached to a vertical pole at $2 \mathrm{~m}$ height.

The aerosol instruments are located in the space below the roof of the tower. Sample air for the instruments is drawn through two parallel sampling lines: One, called the interstitial inlet, is equipped with an impactor with a $10-\mu \mathrm{m}$ cut-off size, followed by a cyclone with a $1.0-\mu \mathrm{m}$ cut-off size $(2.5 \mu \mathrm{m}$ before 20 November 2009), and the other, called the total air inlet, with a heated inlet and snow-hood in order to dry the cloud droplets. The total air inlet has the same construction as that used and designed by Weingartner et al. (1999), who reported that the cut-off size of the inlet is $40 \mu \mathrm{m}$ when the wind speed is below $20 \mathrm{~m} \mathrm{~s}^{-1}$, which is the case most of the time at Puijo. This two-inlet setup enables simultaneous interstitial and total air (interstitial + cloud drop residual) measurements when the tower is covered by clouds. Unless otherwise noted, all measurements described in this paper were made through the interstitial inlet.

We measured the aerosol total and backscattering coefficients at $450 \mathrm{~nm}\left(\sigma_{\mathrm{sp}, 450}\right.$ and $\left.\sigma_{\mathrm{bsp}, 450}\right), 550 \mathrm{~nm}\left(\sigma_{\mathrm{sp}, 550}\right.$ and $\left.\sigma_{\mathrm{bsp}, 550}\right)$, and $700 \mathrm{~nm}\left(\sigma_{\mathrm{sp}, 700}\right.$ and $\left.\sigma_{\mathrm{bsp}, 700}\right)$ by using an integrating nephelometer (TSI Model 3563) (e.g., Anderson et al., 1996). The nephelometer illuminates the sample volume from the side and detects the light scattered by the aerosol particles and gas molecules in the sample with a photomultiplier tube over an angle of $7-170^{\circ}$. The aerosol backscattering coefficient is measured when an internal shutter restricts scattering to between $90-170^{\circ}$. The nephelometer drew the sample out of the interstitial sample line with a flow rate of $8.01 \mathrm{~min}^{-1}\left(101 \mathrm{~min}^{-1}\right.$ before 8 October 2009). The neph- elometer calibration was checked periodically (every three months) with pure carbon dioxide and filtered air. The data collection frequency in the nephelometer was either 1 or $5 \mathrm{~min}$. The relative uncertainty in the scattering coefficient, reported in the literature, is $10 \%$ (Anderson et al., 1996).

We measured the aerosol absorption with a multi-angle absorption photometer (Thermo Model 5012 MAAP). The MAAP (Petzold and Schönlinner, 2004) determines aerosol light absorption by illuminating a particle-loaded filter with $637 \mathrm{~nm}$ (Müller et al., 2011) light and measuring simultaneously the radiation passing through the filter. It also measures the light scattered from the filter at several detection angles in order to resolve the influence of aerosol components that scatter light creating a scattering aerosol artifact. This compensation of light-scattering effects improves considerably the aerosol absorption measurement in filter-based appliances (Bond et al., 1999), especially in the MAAP (Petzold and Schönlinner, 2004). The MAAP was connected to the interstitial sample line and the flow rate through it was $5.01 \mathrm{~min}^{-1}$. We performed periodic checks and flow calibrations for the instrument, and collected the MAAP data every $1 \mathrm{~min}$.

The MAAP provides the absorption information as an equivalent black carbon concentration (EBC), which is obtained by dividing the measured absorption coefficient by a mass absorption coefficient (MAC) of $6.6 \mathrm{~m}^{2} \mathrm{~g}^{-1}$, recommended by the manufacturer. To obtain the absorption coefficient $\left(\sigma_{\mathrm{ap}}, 637\right)$, we multiplied the EBC by the same MAC $\left(6.6 \mathrm{~m}^{2} \mathrm{~g}^{-1}\right)$. It must be noted that the MAC for a specific aerosol can vary during its lifetime and due to changes in its chemical composition, which causes uncertainty in the $\mathrm{EBC}$, if a constant value of MAC is used. For example, values ranging from $6.9-11.6 \mathrm{~m}^{2} \mathrm{~g}^{-1}$ have been reported (Knox et al., 2009; Pandolfi et al., 2011). However, as we used the same MAC value as the MAAP in our calculation, we consider that the variability in MAC as a source of uncertainty can be neglected. For the absorption coefficient, a relative uncertainty of $12 \%$ has been reported by Petzold and Schönlinner (2004).

We analyzed the chemical composition of the aerosols in an intensive campaign 16 September-20 October 2008 by using aerosol mass spectrometry (AMS). The AMS measures the chemical composition of submicron aerosol particles online and in real time. The collection efficiency at the detector approaches $100 \%$ for particles in the size range of 70 $500 \mathrm{~nm}$ (Jayne et al., 2000). The particles are introduced into the AMS through a critical orifice and an aerodynamic lens assembly, producing a narrow aerosol beam that enters an ionization chamber, where non-refractory components flashvaporize and positive ions are detected by Quadrupole mass spectrometer (Q-AMS). A more detailed description of the instrument is given by Jayne et al. (2000). The AMS used in this study gave the concentration of particulate sulphate and organics, and the ratio of $m / z 44$ to $m / z 43$, which indicates 
the degree of oxygenation of organics: the higher the ratio, the more oxygenated the organics.

\subsection{Data processing}

We analyzed the nephelometer and MAAP data covering the time range 1 September 2006-30 September 2010. First we ruled out the unusable data due to abnormal peaks, calibrations, maintenance, flow checks, and autozeroing. Secondly, we omitted the scattering data with the relative humidity higher than $50 \%$ in the nephelometer inlet, because the increasing water content increases the scattering coefficient (Fierz-Schmidhauser et al., 2010) too much compared to dry particles, which we wanted to inspect. We then corrected the valid measured scattering coefficients for truncation errors arising from the physical limitations of the nephelometer (the actual measuring angle is $7-170^{\circ}$, not $0-180^{\circ}$ ), by using the values for no cut at the inlet, given by Anderson and Ogren (1998), and normalized them to standard temperature and pressure $(273.15 \mathrm{~K}$ and $101325 \mathrm{~Pa})$, as described, e.g., in Hänel (1998).

We calculated hourly averages of the valid data for each instrument and used them in the following data analysis. Based on the scattering and absorption coefficients we calculated three intensive properties: the hemispheric backscattering fraction $(b)$, scattering Ångström exponent $\left(\stackrel{\leftrightarrow}{s}_{\mathrm{s}}\right)$, and the single scattering albedo (SSA). All three are dimensionless and independent of the amount of particles.

The $b$ is the ratio of aerosol scattering to the backward hemisphere to the scattering in all directions, and can be used to estimate how much of the incoming solar radiation is reflected backwards. We calculated the $b$ at the wavelengths of 450,550 and $700 \mathrm{~nm}$ for the periods 1 September-30 November 2006 and 1 October 2009-30 September 2010. At other times the backscatter mode in the nephelometer was inactive. We calculated the $\stackrel{\circ}{\mathrm{a}}_{\mathrm{s}}$ for each pair of wavelengths: 700 and $450 \mathrm{~nm}\left(\stackrel{\circ}{a}_{\mathrm{s}, 700-450}\right), 700$ and $550 \mathrm{~nm}\left(\stackrel{\circ}{a}_{\mathrm{s}, 700-550}\right)$, and 550

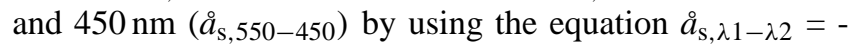
$\left[\log \left(\sigma_{\mathrm{sp}, \lambda 1} / \sigma_{\mathrm{sp}, \lambda 2}\right) / \log \left(\lambda_{1} / \lambda_{2}\right)\right]$.

The SSA is defined as the ratio of the scattering coefficient to the extinction coefficient (the sum of the scattering and absorption coefficients) at a certain wavelength. Since the wavelengths of the nephelometer and MAAP do not match, we determined the scattering coefficient at $637 \mathrm{~nm}\left(\sigma_{\mathrm{sp}, 637}\right)$ by using the Ångström power law, $\sigma_{\mathrm{sp}, 637}=$ $\sigma_{\mathrm{sp}, 550} *(637 / 550)^{-\mathrm{a} s}, 700-550$. The SSA at $637 \mathrm{~nm}$ was then calculated as $\mathrm{SSA}_{637}=\sigma_{\mathrm{sp}, 637} /\left(\sigma_{\mathrm{ap}, 637}+\sigma_{\mathrm{sp}, 637}\right)$. By applying the law for propagation of errors to the relative uncertainties in the scattering and absorption coefficients given above, we obtained an upper limit of $13 \%$ for the relative uncertainty in the SSA.

We calculated monthly averages for the scattering and absorption coefficients and the SSA, and sorted the data for each month in order to calculate the 10th, 50th (median) and 90th percentiles as an indicator for the variability of the pa- rameter values each month. We excluded rainy periods with a precipitation intensity more than $0.2 \mathrm{~mm} \mathrm{~h}^{-1}$, whose occurrence was, on an average, $11 \%$ of the time. We also excluded cloudy periods lasting more than $15 \mathrm{~min}$ ( $4 \%$ of the valid data), i.e. the periods when the tower was covered by lowlevel clouds. The indication of the presence of a cloud was adopted from Portin et al. (2009), who defined a cloud event by a sudden drop in the horizontal visibility below $200 \mathrm{~m}$ and a burst in cloud droplet concentration measured by a Cloud Droplet Probe.

In order to examine the effect of cloud events on the aerosol optical properties we separated the optical properties measured from the interstitial and total sampling lines for a four-day period (7-11 October 2010). For this special case, the nephelometer and MAAP were connected to a four-valve system, which changes the sampling inlets of the instruments in 6-min cycles. During the cycle 1 the MAAP was connected to the interstitial line and the nephelometer to the total air line and during the cycle 2 vice versa. In this setup the MAAP flow was increased to $8.01 \mathrm{~min}^{-1}$ in order to maintain equal flow rates in both inlets.

\subsection{Local source analysis}

We divided the measured and calculated parameters according to the prevailing wind direction into (1) equal, 22.5degree sectors and (2) five sectors described below, in order to analyse the effect of the local pollutant sources. Furthermore, we inspected the average diurnal cycles for each month in order to identify the effects of daily (e.g., traffic) and seasonally (e.g., domestic wood combustion) time-dependent sources. The major point sources around Puijo are a paper mill $\left(5 \mathrm{~km}\right.$ in the direction of $\left.35^{\circ}\right)$ and a district heating plant $\left(3.5 \mathrm{~km}, 160^{\circ}\right)$. A distinct line source, the Route $5 / \mathrm{E} 63$ highway, runs from north $\left(6^{\circ}\right)$ to south $\left(192^{\circ}\right)$. The most important area sources are the eastern residential areas (1.2$4.0 \mathrm{~km}$ in the sector of $\left.45-120^{\circ}\right)$, the city center $(1.6-3.2 \mathrm{~km}$, $\left.120-155^{\circ}\right)$, the southern residential areas $(3.4-10 \mathrm{~km}, 155-$ $245^{\circ}$ ), and the western residential areas $(1.5-3.5 \mathrm{~km}, 245-$ $360^{\circ}$ ). Based on the distances and bearings of the pollutant sources, the chosen sectors were (1) $0-45^{\circ}$, including the northern highway and the paper mill, (2) $45-155^{\circ}$, including the city center and the eastern residential areas, extending up to $4 \mathrm{~km}$, (3) $155-215^{\circ}$, including the district heating plant and the southern residential areas extending up to $10 \mathrm{~km}$, (4) $215-245^{\circ}$, including the southwestern residential areas extending up to $4 \mathrm{~km}$, and (5) $245-360^{\circ}$, including the western residential areas, extending up to $1-3 \mathrm{~km}$.

It must be noted that the measurements were made approximately $230 \mathrm{~m}$ above the release height of the traffic and domestic emissions, which are diluted before they reach the measurement point. Furthermore, when the mixing layer height is below the top of the tower (e.g., in the winter in the nighttime), the emissions from the very nearby sources 
Table 1. Number $(N)$, average, standard deviation (std), 10th, 50th, and 90th percentiles, and maxima (max) of valid observations for aerosol scattering and backscattering coefficients at 450,550 , and $700 \mathrm{~nm}\left(\sigma_{\mathrm{sp}, 450}, \sigma_{\mathrm{bsp}, 450}, \sigma_{\mathrm{sp}, 550}, \sigma_{\mathrm{bsp}, 550}, \sigma_{\mathrm{sp}, 700}\right.$, and $\sigma_{\mathrm{bsp}, 700}$ in $\left.\mathrm{Mm}{ }^{-1}\right)$, hemispheric backscattering fractions at 450,550 , and $700 \mathrm{~nm}\left(b_{450}, b_{550}\right.$, and $\left.b_{700}\right)$, Ångström exponents between 550 and $450 \mathrm{~nm}, 700$ and

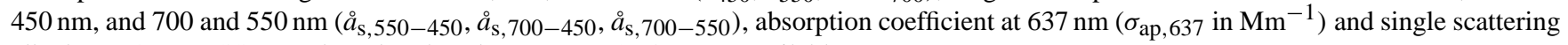
albedo at $637 \mathrm{~nm}\left(\mathrm{SSA}_{637}\right)$ based on hourly averages. $* \mathrm{~N} / \mathrm{A}=$ not available.

\begin{tabular}{|c|c|c|c|c|c|c|c|}
\hline \multirow[b]{2}{*}{ parameter } & \multirow[b]{2}{*}{$N$} & \multirow[b]{2}{*}{ average } & \multirow[b]{2}{*}{ std } & \multicolumn{3}{|c|}{ percentiles } & \multirow[b]{2}{*}{$\max$} \\
\hline & & & & 10 & 50 & 90 & \\
\hline$\sigma_{\mathrm{sp}, 450}$ & 20530 & 17.2 & 20.7 & 3.1 & 10.8 & 38.3 & 396.2 \\
\hline$\sigma_{\mathrm{sp}, 550}$ & 20482 & 11.6 & 14.3 & 2.2 & 7.2 & 25.9 & 300.7 \\
\hline$\sigma_{\mathrm{sp}, 700}$ & 20492 & 6.9 & 8.9 & 1.4 & 4.4 & 15.0 & 216.3 \\
\hline$\sigma_{\mathrm{bsp}, 450}$ & 4500 & 2.4 & 3.6 & 0.3 & 1.4 & 5.5 & 47.6 \\
\hline$\sigma_{\mathrm{bsp}, 550}$ & 4493 & 1.9 & 2.7 & 0.3 & 1.1 & 4.1 & 35.8 \\
\hline$\sigma_{\mathrm{bsp}, 700}$ & 3860 & 2.0 & 2.8 & 0.1 & 1.2 & 4.5 & 33.2 \\
\hline$b_{450}$ & 4500 & 0.15 & 0.13 & 0.09 & 0.14 & 0.21 & N/A* \\
\hline$b_{550}$ & 4492 & 0.18 & 0.21 & 0.12 & 0.17 & 0.25 & N/A \\
\hline$b_{700}$ & 3860 & 0.55 & 2.5 & 0.13 & 0.22 & 0.73 & N/A \\
\hline$\stackrel{\circ}{\mathrm{s}}, 550-450$ & 20530 & 1.87 & 0.71 & 1.11 & 1.93 & 2.50 & 13.9 \\
\hline$\stackrel{\circ}{a}_{\mathrm{s}, 700-450}$ & 20483 & 1.95 & 0.62 & 1.21 & 2.02 & 2.47 & 10.7 \\
\hline 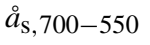 & 20492 & 2.02 & 0.86 & 1.16 & 2.10 & 2.56 & 19.5 \\
\hline$\sigma_{\mathrm{ap}, 637}$ & 26820 & 1.6 & 1.8 & 0.3 & 1.0 & 3.4 & 38.9 \\
\hline $\mathrm{SSA}_{637}$ & 20288 & 0.84 & 0.09 & 0.73 & 0.85 & 0.93 & 0.99 \\
\hline
\end{tabular}

might pass under the measurement point and would not be observed.

\subsection{Trajectory analysis}

In order to explore long-range transport of air masses to the site, we calculated 120-hour backward trajectories for the period from September 2006 to September 2010 in threehour intervals, using the FLEXTRA trajectory model (Stohl et al., 1995). We adopted from Leskinen et al. (2009) the classification of the trajectories into five air mass arrival sectors, named as Arctic $\left(315-10^{\circ}\right)$, Arctic/Kola $\left(10-70^{\circ}\right)$, East $\left(70-160^{\circ}\right)$, South $\left(160-235^{\circ}\right)$ and West $\left(235-315^{\circ}\right)$. The East and South sectors represent the continental air/sources from Russia and Europe, respectively. The West sector covers the Northern Atlantic and the Arctic sector the Arctic Ocean. We furthermore divided the Arctic sector into two sectors in order to separate the Kola Peninsula sources from the clean Arctic air. We classified each trajectory according to its main sector, i.e. the sector where it had spent most of the time during the last $120 \mathrm{~h}$. It must be noted that these sectors do not match with the wind direction sectors determined by the local pollutant sources. Therefore, we calculated, for each local source sector, the percentages of time that the air masses had spent in each long-range transport sector before arriving at Puijo.

\section{Results and discussion}

\subsection{Meteorological parameters}

The temperature, relative humidity and horizontal visibility had clear seasonal cycles (Fig. 2), with averages over the four-year period of $3.2{ }^{\circ} \mathrm{C}, 80 \% \mathrm{RH}$, and $28 \mathrm{~km}$. February 2007 and January-February 2010 were found to be exceptionally cold subperiods, with average temperatures of $-12.8^{\circ} \mathrm{C}$ and $-12.5^{\circ} \mathrm{C}$, and minimum temperatures of $-22.6^{\circ} \mathrm{C}$ and $-27.4^{\circ} \mathrm{C}$, respectively. The July 2010 was, in turn, exceptionally warm throughout the Eastern Europe (Barriopedro et al., 2011), with a maximum hourly average of $32.9^{\circ} \mathrm{C}$ at Puijo (Fig. 2a). The median of the relative humidity was, in general, below $80 \%$ in April-August, and exceeded $95 \%$ in October-December (Fig. 2b). The 10th percentile of the visibility was, in general, below $200 \mathrm{~m}$ in October-April (Fig. 2c). The periods with high relative humidity and low visibility are optimal for investigating lowlevel clouds, as will be discussed in Sect. 3.6.

\subsection{Aerosol scattering and absorption}

During the measurement period (2006-2010) the average scattering coefficients, based on 20500 hourly-averaged observations of the total scattering at 450,550 , and $700 \mathrm{~nm}$, were $17.2,11.6$, and $6.9 \mathrm{Mm}^{-1}$, respectively (Table 1 ). The average of the $\sigma_{\mathrm{sp}, 550}$ is somewhat lower than that observed at another Finnish site in Hyytiälä, $200 \mathrm{~km}$ from Puijo (18 $\mathrm{Mm}^{-1}$; Virkkula et al., 2011) but higher than those observed at remote Arctic sites (e.g., Delene and Ogren, 2002; 

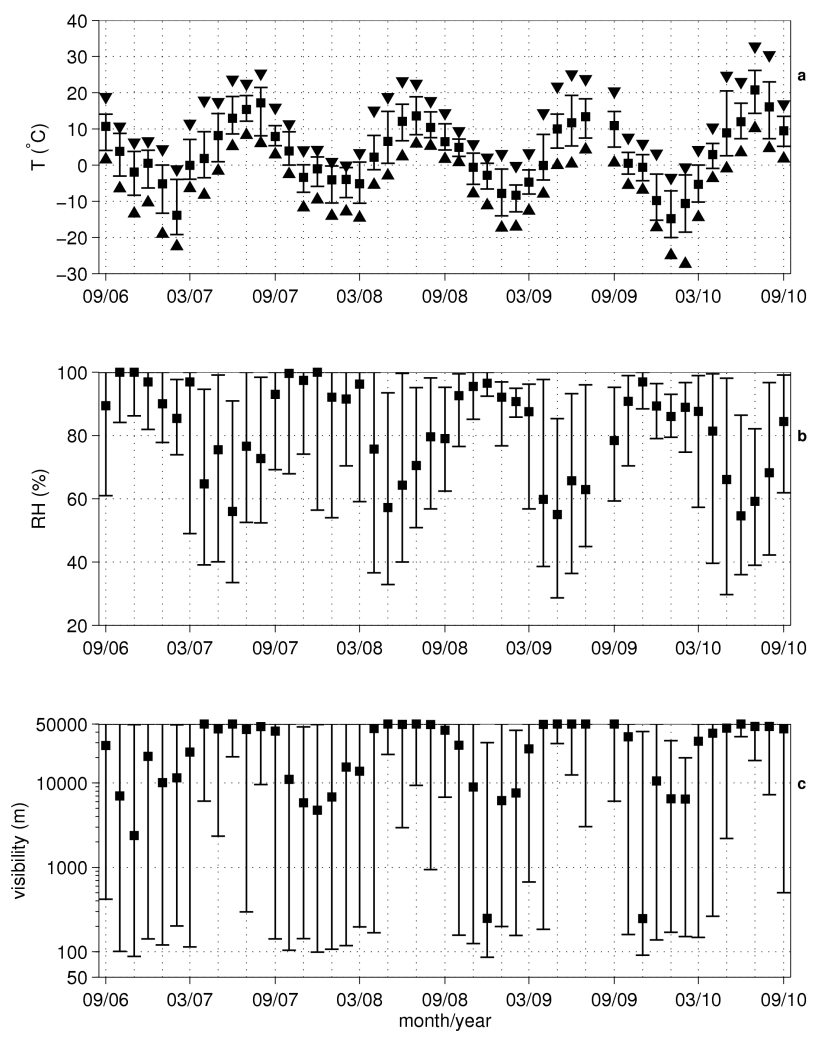

Fig. 2. Monthly minimum (triangle up; only for temperature), 10th percentile (lower error bar), median (square), 90th percentile (upper error bar), and maximum (triangle down; only for temperature) of (a) temperature, (b) relative humidity, and (c) horizontal visibility at Puijo in September 2006-September 2010.

Aaltonen et al., 2006). The long-time average of the $\sigma_{\mathrm{ap}, 637}$ at Puijo was $1.6 \mathrm{Mm}^{-1}$, which is again lower than the value in Hyytiälä (2.1 $\mathrm{Mm}^{-1}$; Virkkula et al., 2011) but higher than the values at Arctic sites (e.g., Delene and Ogren, 2002). This comparison puts Puijo into a relatively clean class, when regarding the aerosol optical properties. However, as we will discuss in Sect. 3.5., the aerosol scattering and absorption coefficients at Puijo occasionally reach values comparable to those in highly polluted areas.

The annual cycle of $\sigma_{\mathrm{sp}, 550}$ showed strong seasonality, with its peak 90-percentile values in the spring (February, March, or April, depending on the year) and autumn (August, September, or October, depending on the year) (Fig. 3a). The seasonal variation was similar also at $450 \mathrm{~nm}$ and $700 \mathrm{~nm}$. The summer of 2010 was an exception to this pattern, because long-transported aerosol from forest fires in Russia increased the total scattering coefficients, as will be discussed in Sect. 3.5. The gaps in the data in Fig. 3a are due to maintenance of the instrument or its deployment at another measurement site.

The average of the backscattering coefficient at 450,550 , and $700 \mathrm{~nm}$ was $3.3,2.5$, and $2.6 \mathrm{Mm}^{-1}$ for the 12 months
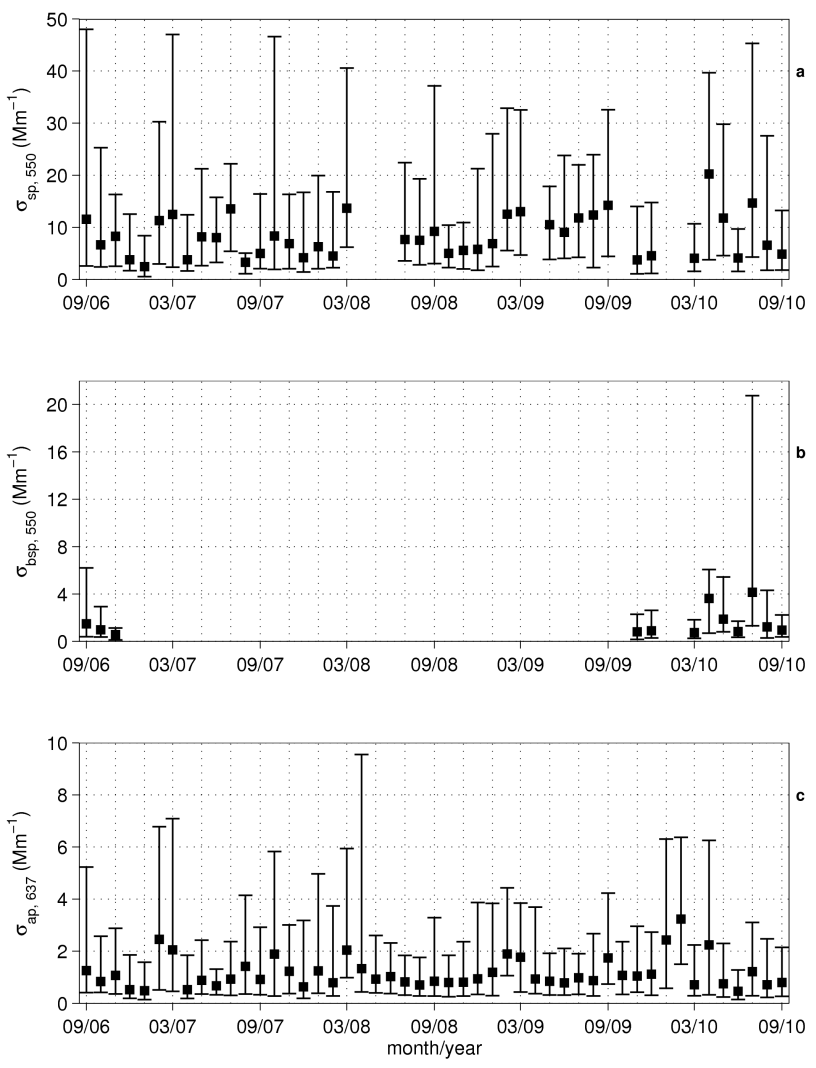

Fig. 3. Monthly 10th percentile (lower error bar), median (square), and 90th percentile of (a) total scattering coefficient at $550 \mathrm{~nm}$, (b) back scattering coefficient at $550 \mathrm{~nm}$, and (c) absorption coefficient at $637 \mathrm{~nm}$ at Puijo in September 2006-September 2010.

when this measurement was active. This results in an average ( \pm 1 standard deviation) hemispheric backscattering fraction of $0.13 \pm 0.04$ at $550 \mathrm{~nm}$. For the backscattering coefficient at $550 \mathrm{~nm}$ (Fig. 3b) a seasonal trend cannot be determined due to inactive backscatter mode in the nephelometer between 1 December 2006-31 October 2009, but overall the monthly median of the hemispheric backscatter fraction varied between 0.10-0.15 (Fig. 4a). The $b$ measured at Puijo is in the same range as $b$ reported for a wide variety of location types (e.g., Delene and Ogren 2002; Aaltonen et al., 2006; Virkkula et al., 2011).

The $\sigma_{\mathrm{ap}, 637}$ peaked, depending on the year, in JanuaryMarch, when the monthly median was $1.8-3.2 \mathrm{Mm}^{-1}$ (Fig. 3c). The maximum of the hourly averages, $38.9 \mathrm{Mm}^{-1}$, was observed in January 2008. During the other months the median ranged between $0.5-1.7 \mathrm{Mm}^{-1}$. The higher values in the early spring are connected to low temperatures observed during these months (Fig. 2a). During cold weather and dark months the heating and power plants are operating at full stretch and people tend to increase wood burning in domestic combustion appliances, which produces, among others, particles that contain more black carbon, a good absorber of light. 

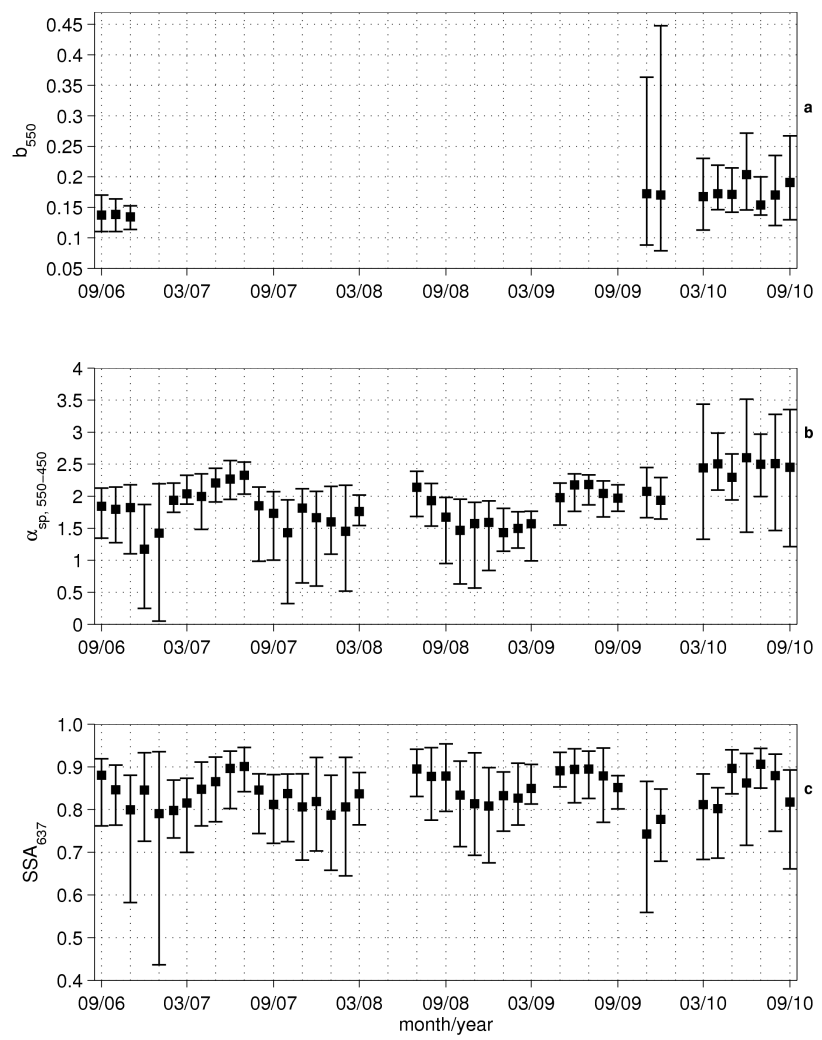

Fig. 4. Monthly 10th percentile (lower error bar), median (square), and 90th percentile of (a) hemispheric backscattering fraction at $550 \mathrm{~nm}$, (b) scattering Ångström exponent between 450 and $550 \mathrm{~nm}$, and (c) single scattering albedo at $637 \mathrm{~nm}$ at Puijo in Sep 2006-Sep 2010.

The seasonal variation - as well as the long-term statistics of $\sigma_{\mathrm{ap}, 637}$ was similar to that observed in Hyytiälä (Virkkula et al., 2011).

\subsection{Scattering Ångström exponent and single scattering albedo}

The long-time averages of the $\stackrel{\circ}{\mathrm{s}}_{\mathrm{s}}$ for each pair of wavelengths $(450 / 550 \mathrm{~nm}, 450 / 700 \mathrm{~nm}$ and $550 / 700 \mathrm{~nm})$ were nearly equal, ranging between 1.87 and 2.02 (Table 1). From here on, we designate the scattering Ångström exponent for the $450 / 550 \mathrm{~nm}$ pair by $\stackrel{\circ}{a}_{\mathrm{s}}$. The $\stackrel{\circ}{\mathrm{a}}_{\mathrm{s}}$ is lowest in the wintertime, with its median being lowest, 1.17, in December 2006 and highest, 2.6, in June 2010 (Fig. 4b). The average $\stackrel{\circ}{s}_{\mathrm{s}}$ at Puijo is somewhat higher than the average $\stackrel{\circ}{\mathrm{s}}_{\mathrm{s}}$ of $1.7-1.8$ at Pallas (Aaltonen et al., 2006) and the average $\stackrel{\circ}{\mathrm{s}}_{\mathrm{s}}$ of 1.7 in Hyytiälä (Virkkula et al., 2011). This indicates that at Puijo the scattering aerosol particles are relatively small in size.

It must be noted that the $\stackrel{\circ}{\mathrm{S}}_{\mathrm{S}}$ values increased, on an average, by $39 \%$ after November 2009 (achieving the maximum value 2.59 in June 2010), when we changed the cut-off size of the interstitial inlet from $2.5 \mu \mathrm{m}$ to $1.0 \mu \mathrm{m}$ (Fig. $4 \mathrm{~b}$ ). This
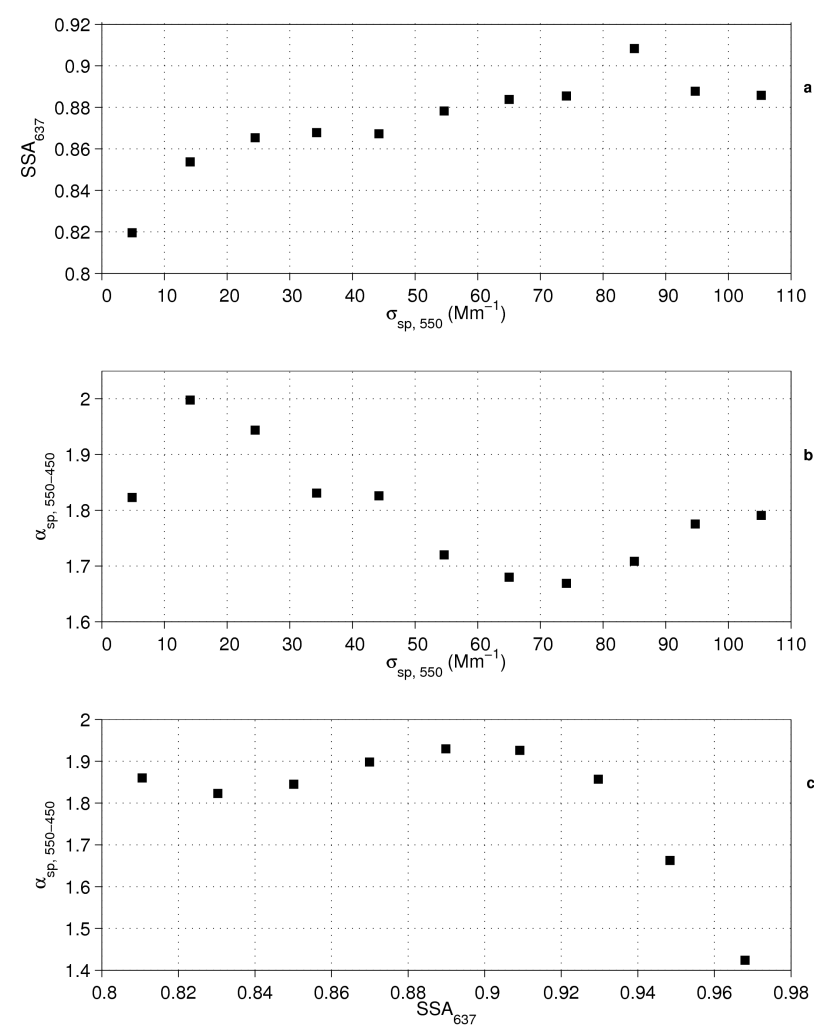

Fig. 5. (a) Mean single scattering albedo $\left(\mathrm{SSA}_{637}\right)$ classified according to $10-\mathrm{Mm}^{-1}$ bins of the scattering coefficient at $550 \mathrm{~nm}$ $\left(\sigma_{\mathrm{sp}, 550}\right)$, (b) mean scattering Ångström exponent between 550 and $700 \mathrm{~nm}$ classified according to $10-\mathrm{Mm}^{-1}$ bins of the scattering coefficient at $550 \mathrm{~nm}\left(\sigma_{\mathrm{sp}, 550}\right)$, and (c) mean scattering Ångström exponent between 550 and $700 \mathrm{~nm}$ classified according to 0.02 bins of the single scattering albedo $\left(\mathrm{SSA}_{637}\right)$.

means that fewer coarse particles are nowadays present in

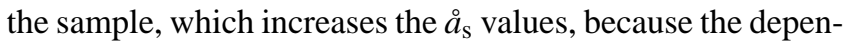
dence of the light scattering on the wavelength of the incident light is stronger for smaller particles.

The SSA was lowest in the winter and highest in the summer (Fig. 4c). The average ( \pm 1 standard deviation) SSA was $(0.83 \pm 0.09)$, which is somewhat lower than the SSA at $550 \mathrm{~nm}$, observed in Hyytiälä $(0.88 \pm 0.07$; Virkkula et al., 2011). Since the SSA is wavelength dependent, we estimated, by using the data from Virkkula et al. (2011), the SSA at $637 \mathrm{~nm}$ in Hyytiälä to be 0.89 .

We adopted the analysis for the SSA vs. the $\sigma_{\mathrm{sp}, 550}$ and the $\stackrel{\circ}{\mathrm{S}}_{\mathrm{S}} \mathrm{vs} . \sigma_{\mathrm{sp}, 550}$ from Delene and Ogren (2002) and found that the SSA at Puijo increases with increasing $\sigma_{\mathrm{sp}, 550}$ (Fig. 5a). Our conclusion is, similarly to that made by Delene and Ogren (2002) for Barrow, Alaska, that the absorption at Puijo does not increase as rapidly as the scattering. The $\stackrel{a}{\mathrm{~s}}_{\mathrm{s}}$ vs. $\sigma_{\mathrm{sp}, 550}$, in turn, shows a more complicated relationship (Fig. $5 \mathrm{~b}$ ). First, at low $\sigma_{\mathrm{sp}, 550}$ values, the $\stackrel{\circ}{\mathrm{s}}_{\mathrm{s}}$ increases, peaking at the $10-20 \mathrm{Mm}^{-1}$-bin. When the $\sigma_{\mathrm{sp}, 550}$ further 
Table 2. The averages of the aerosol optical parameters over the chosen sectors with emission sources: highway, paper mill, city center, district heating plant, and residential areas (RA) extending up to $10 \mathrm{~km}$. Please see caption of Table 1 for explanation of the parameters.

\begin{tabular}{lrrrrr}
\hline Sector & $\begin{array}{r}0-45^{\circ}, \\
\text { highway and } \\
\text { paper mill }\end{array}$ & $\begin{array}{r}45-155^{\circ}, \mathrm{RA} \\
(0-4 \mathrm{~km}) \text { and } \\
\text { city center }\end{array}$ & $\begin{array}{r}155-215^{\circ}, \mathrm{RA} \\
(0-10 \mathrm{~km}) \text { and } \\
\text { district heating plant }\end{array}$ & $\begin{array}{r}215-245^{\circ}, \mathrm{RA} \\
(0-4 \mathrm{~km})\end{array}$ & $\begin{array}{r}245-360^{\circ}, \mathrm{RA} \\
(0-3 \mathrm{~km})\end{array}$ \\
\hline$\sigma_{\mathrm{sp}, 450}$ & 19.5 & 21.5 & 22.1 & 16.8 & 10.6 \\
$\sigma_{\mathrm{sp}, 550}$ & 13.2 & 14.4 & 15.0 & 11.4 & 7.2 \\
$\sigma_{\mathrm{sp}, 700}$ & 7.8 & 8.5 & 9.0 & 6.8 & 4.4 \\
$\sigma_{\mathrm{bsp}, 450}$ & 1.5 & 3.3 & 3.1 & 2.9 & 1.4 \\
$\sigma_{\mathrm{bsp}, 550}$ & 1.1 & 2.5 & 2.3 & 2.1 & 1.1 \\
$\sigma_{\mathrm{bsp}, 700}$ & 1.2 & 2.6 & 2.7 & 2.1 & 1.3 \\
$b_{450}$ & 0.15 & 0.15 & 0.15 & 0.14 & 0.15 \\
$b_{550}$ & 0.17 & 0.19 & 0.19 & 0.17 & 0.18 \\
$b_{700}$ & 0.31 & 0.67 & 1.92 & 0.32 & 0.52 \\
$a_{\mathrm{s}, 550-450}$ & 1.92 & 1.99 & 2.5 & 1.83 & 1.76 \\
$\sigma_{\text {ap }, 637}$ & 1.2 & 2.0 & 0.79 & 0.83 & 0.9 \\
$\mathrm{SSA}_{637}$ & 0.87 & 0.83 & & 0.8 & 0.85 \\
\hline
\end{tabular}

increases, the $\dot{a}_{\mathrm{S}}$ starts to decrease, which is similar to the findings of Delene and Ogren (2002) in Barrow, Alaska. But when the $\sigma_{\mathrm{sp}, 550}$ value of $80 \mathrm{Mm}^{-1}$ is exceeded, the $\stackrel{\circ}{\mathrm{s}}_{\mathrm{s}}$ increases again. On the contrary, the scattering Ångström exponent is almost constant with increasing SSA until the SSA exceeds 0.9 (Fig. 5c). For higher SSA values the scattering Ångström exponent decreases rapidly. This indicates that the scattering is more effective than absorption for large particles with a low $\stackrel{\circ}{a}_{\mathrm{s}}$.

It must be noted that the scattering coefficient at Puijo was measured at relatively dry conditions $(\mathrm{RH}<50 \%)$. Therefore, the ambient scattering coefficient and SSA may be underestimated, because the actual scattering coefficient at ambient conditions can be several times larger for the same aerosol than at dry conditions (Zieger et al. 2010). A correction to match the ambient conditions would probably increase the in situ SSA. However, as we have not determined the scattering enhancement factor at Puijo, we can only present the SSA based on the scattering coefficient at dry conditions.

\subsection{The effect of local sources on aerosol optical and chemical properties}

The $\sigma_{\mathrm{sp}, 550}$ is highest when the wind blows from the directions of traffic, industry, and residential areas (Table 2). It experiences a local maximum when the wind blows from the northeast, i.e. the direction where the paper mill resides (Fig. 6a). In our earlier study we found that the air masses coming from this direction were rich in sulphur dioxide (Leskinen et al., 2009), which quickly converts into sulphate and particulate sulphate, one of the main anthropogenic scattering components.

The $\sigma_{\mathrm{ap}, 637}$ is largest with southerly winds and above the long-time average of $1.6 \mathrm{Mm}^{-1}$ when the wind blows from
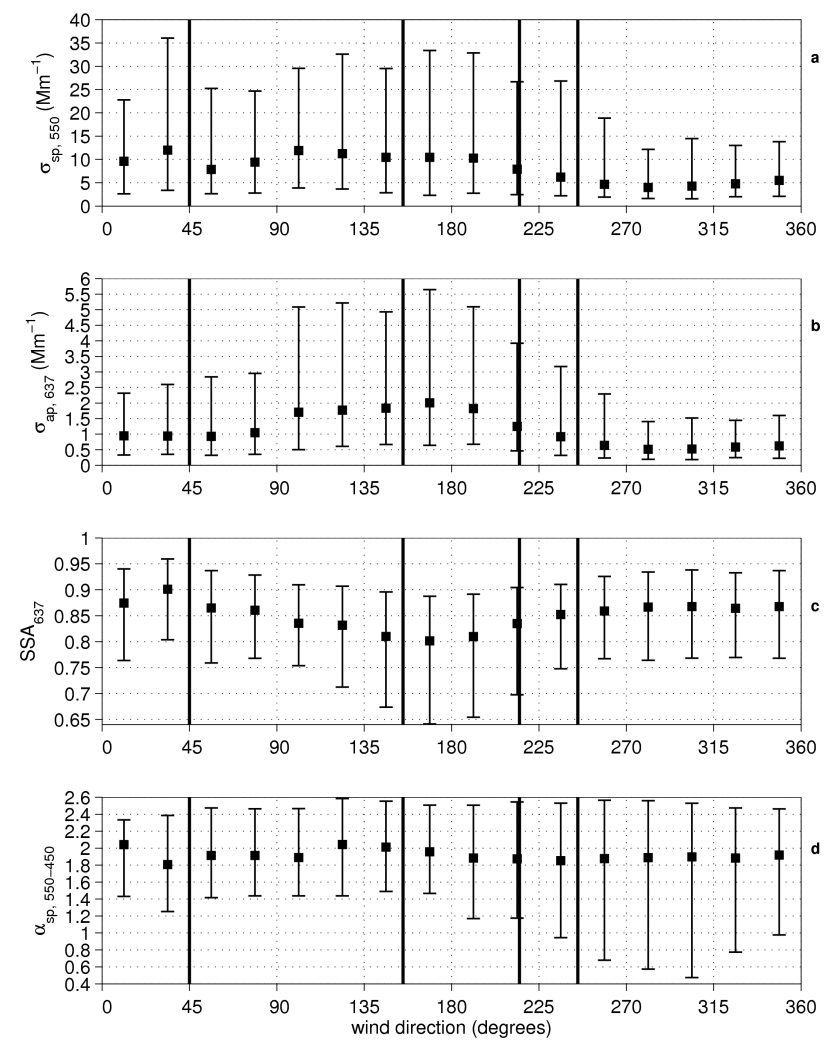

Fig. 6. The 10th percentile (lower error bar), median (square), and 90th percentile of (a) total scattering coefficient at $550 \mathrm{~nm}$, (b) absorption coefficient at $637 \mathrm{~nm}$, (c) single scattering albedo at $637 \mathrm{~nm}$, and (d) scattering Ångström exponent between 450 and $550 \mathrm{~nm}$ as a function of wind direction at Puijo in Sep 2006-Sep 2010. The vertical lines are the limits for the geographical sectors for local source analysis. 
the southern highway and larger residential areas (Fig. 6b). These are line and areal sources of diesel particles and emissons from small-scale, biomass-fired (mainly wood) combustion appliances, respectively. Their emissions contain, among other, soot, which absorbs light efficiently. As expected, we observed the lowest $\sigma_{\mathrm{ap}, 637}$ with winds from the sector 245$360^{\circ}$ with least local sources (Fig. 1; Table 2).

The effect of the the local sources can be seen more clearly from the variation in the SSA and the $\stackrel{\circ}{\mathrm{s}}_{\mathrm{s}}$ with the wind direction (Fig. $6 \mathrm{c}-\mathrm{d}$ ). The $\stackrel{\circ}{\mathrm{s}}_{\mathrm{s}}$ is larger, indicated by higher 10th percentiles, for the directions of local sources, whose particles are fresh and smaller in size than the aged particles coming from longer distances. The SSA, in turn, reaches its maximum value of 0.90 when the air masses come from the northeasterly sector, indicating highly scattering aerosol from the paper mill, and its minimum value of 0.81 when the wind blows from the southerly sector with highway and large residential area (Fig. 1; Table 2).

The AMS analysis showed a 2-3-fold larger particulate sulfate concentration with northeasterly winds compared to other wind directions (Fig. 7a). The peak concentration from the direction of the paper mill gives an explanation to the elevated scattering from this direction. The emissions from the south contain 4-5-fold organics than those from the north (Fig. 7b). With northwesterly winds the degree of oxygenation is higher (Fig. 7c), which is due to the oxygenated organics in the aged aerosol particles (e.g., Aiken et al. 2008) from the direction with less local sources.

The diurnal variation of the $\sigma_{\mathrm{ap}, 637}$ and the SSA showed morning (at $\sim 06: 00-08: 00 \mathrm{UTC}+2$ ) and afternoon (at $\sim$ 17:00-19:00 UTC +2) peaks in May-August (Fig. 8ab). This is linked to the increased traffic at these hours. We suggest that in the winter the emissions from traffic are masked by a higher amount of more absorbing particles from other local sources, such as domestic biomass burning appliances. These sources are expected to be active mainly during the daytime and in the evenings. The nightly $\sigma_{\mathrm{ap}, 637}$ was lower than that in the daytime in all months, with a corresponding decrease in scattering, resulting in higher SSA values at night.

\subsection{The effects of long-range transported aerosol}

The Puijo station was influenced by long-transported aerosol from forest fires in Russia on 29 July and 8 August 2010. On these episode days the average of the $\sigma_{\mathrm{sp}, 550}$ was $169 \mathrm{Mm}^{-1}$, which is 23.5 times the average of the off-episode $\sigma_{\mathrm{sp}, 550}$ values. Accordingly, the average of the $\sigma_{\mathrm{ap}, 637}$ on the episode days was $8.12 \mathrm{Mm}^{-1}$, which is 12.5 times the average of the off-episode $\sigma_{\mathrm{ap}, 637}$ values (Portin et al., 2012). The maximum hourly average of the $\sigma_{\mathrm{sp}, 550}$ and $\sigma_{\mathrm{ap}, 637}$ during the episodes was $301 \mathrm{Mm}^{-1}$ and $14.3 \mathrm{Mm}^{-1}$, respectively. The forest fire episodes did not increase the $\sigma_{\mathrm{ap}, 637}$ as much as the $\sigma_{\mathrm{sp}, 550}$, which could be explained by the domination of aged aerosol particles with less absorptive constituents dur-
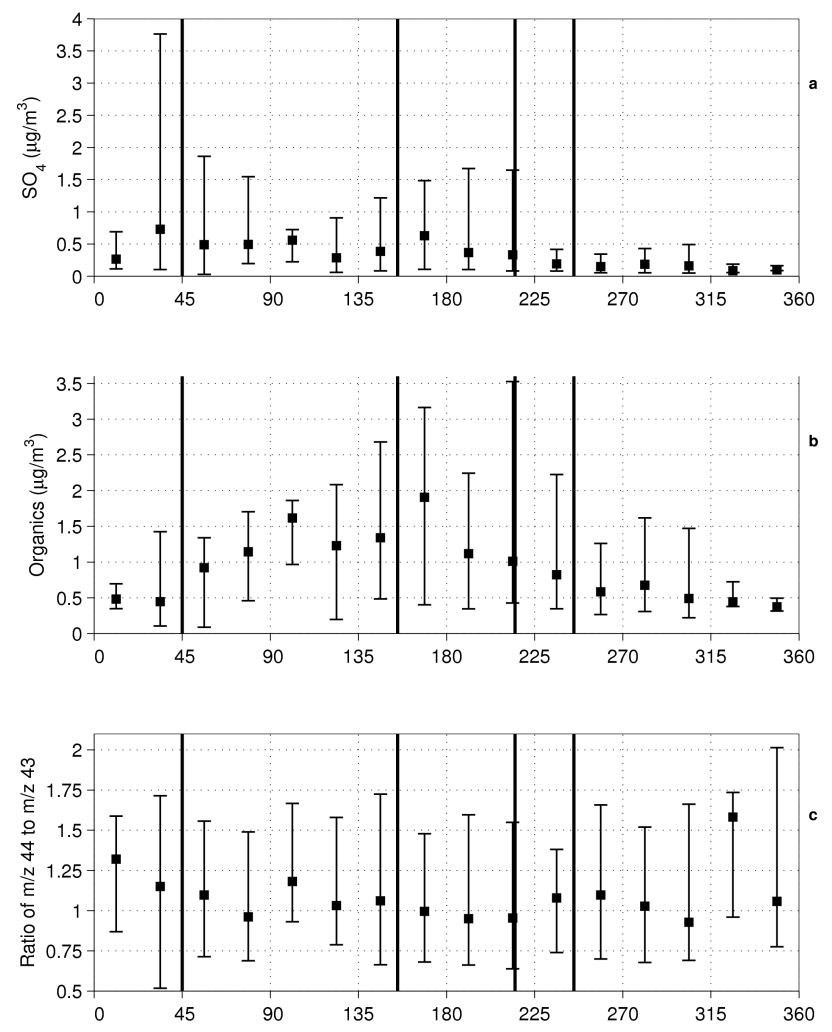

Fig. 7. The 10th percentile (lower error bar), median (square), and 90th percentile of (a) sulphate concentration, (b) organics concentration, and (c) the ratio of mass numbers 44 to 43 in non-refractory submicron particles as a function of wind direction at Puijo, averaged over the time period of 16 September-20 October 2008. The vertical lines are the limits for the geographical sectors for local source analysis.

ing the smoke episodes. A similar finding was done by Fischer et al. (2010), who found that in an aged pollution plume the SSA was higher than in another plume originating nearer the source.

At Puijo the air masses entering from the northwesterly sector $\left(245-360^{\circ}\right)$ can be considered as background air. There are only a small amount of residential sources in this sector (Fig. 1). When the wind blows from the northwesterly sector, the air masses have spent most of the time (73\%) during the last 5 days over the Arctic and West long-range transport sectors (Fig. 9), which are considered clean. Furthermore, with less local or nearby sources, the air masses from this sector can be regarded as a representative of an aged aerosol. For the aged aerosol the SSA was higher than for the aerosol emerging from local sources (excluding the paper mill) in the southerly sector (Fig. 6c). Also the statistic of the Angström exponent showed considerably many low values (Fig. 6d), indicating larger aerosol particles, which is often true for an aged aerosol (e.g., Seinfeld and Pandis, 2006). 

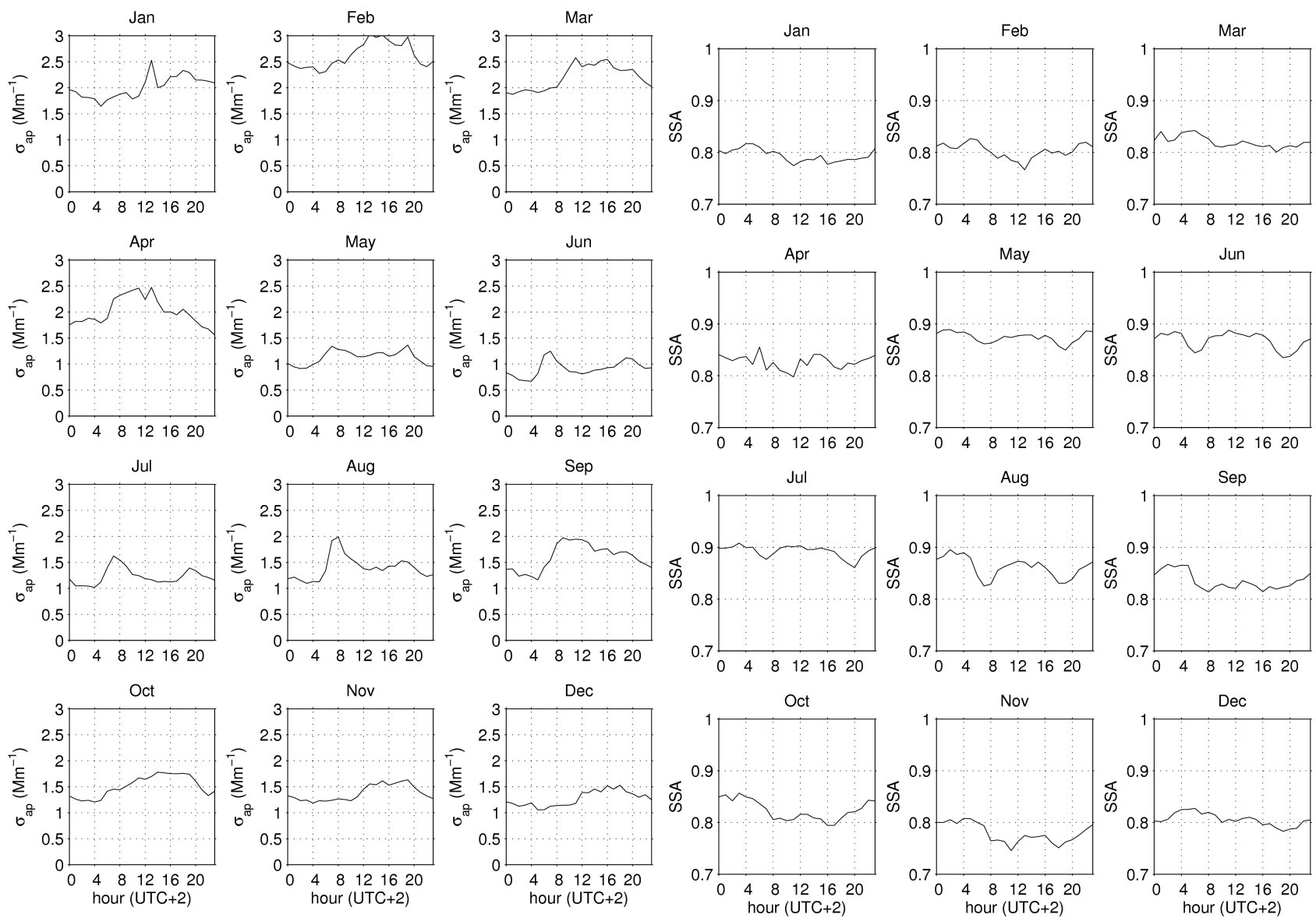

Fig. 8. The (a) absorption coefficient at $637 \mathrm{~nm}$ and (b) single scattering albedo at $637 \mathrm{~nm}$ as a function of hour (UTC +2$)$ and month at Puijo. The months of the years 2006-2010 were combined. The local noon is at 13:00 o'clock during the daylight saving time in Europe and at 12:00 o'clock at other times.

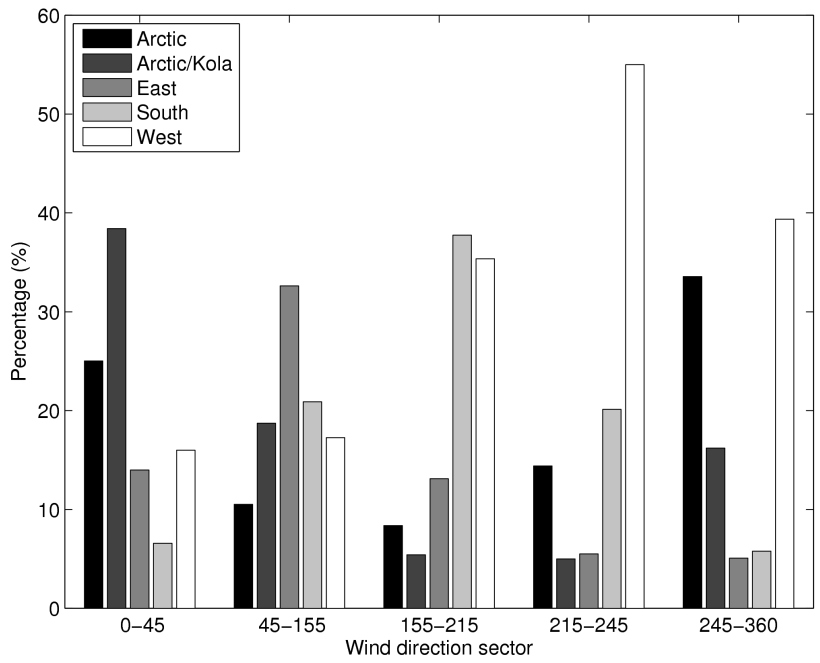

Fig. 9. The distribution of air mass origins (trajectory sectors) with each local source sector.

\subsection{A case study for cloud effects on aerosol optical properties}

We investigated the effect of a cloud event on aerosol optical properties for a four-day period on 7-11 October 2010 (Fig. 10). During this period we observed two cloud events. The first event started on 8 October 2010, 10:45 and lasted $2.5 \mathrm{~h}$, while the second event started on 8 October 2010, $21: 45$ and lasted 8 hours. Before the first cloud event the wind was blowing from the southwestern sectors $\left(200-250^{\circ}\right)$ with residential areas, resulting in a higher $\sigma_{\mathrm{ap}, 637}$, compared to that observed after the second cloud event, when the wind was blowing from the northwesterly sector $\left(245-360^{\circ}\right)$, with relatively clean and aged aerosol. There was no rain until 10 October 2010, 08:00, i.e. well after the second cloud event.

During the two investigated cloud events both the interstitial and total aerosol scattering and absorption coefficients decreased (Fig. 10). The effect is stronger for the scattering than for absorption. The scattering and absorption coefficients of the interstitial particles are by more than $90 \%$ and $30 \%$ smaller than that of the total aerosol particles during 

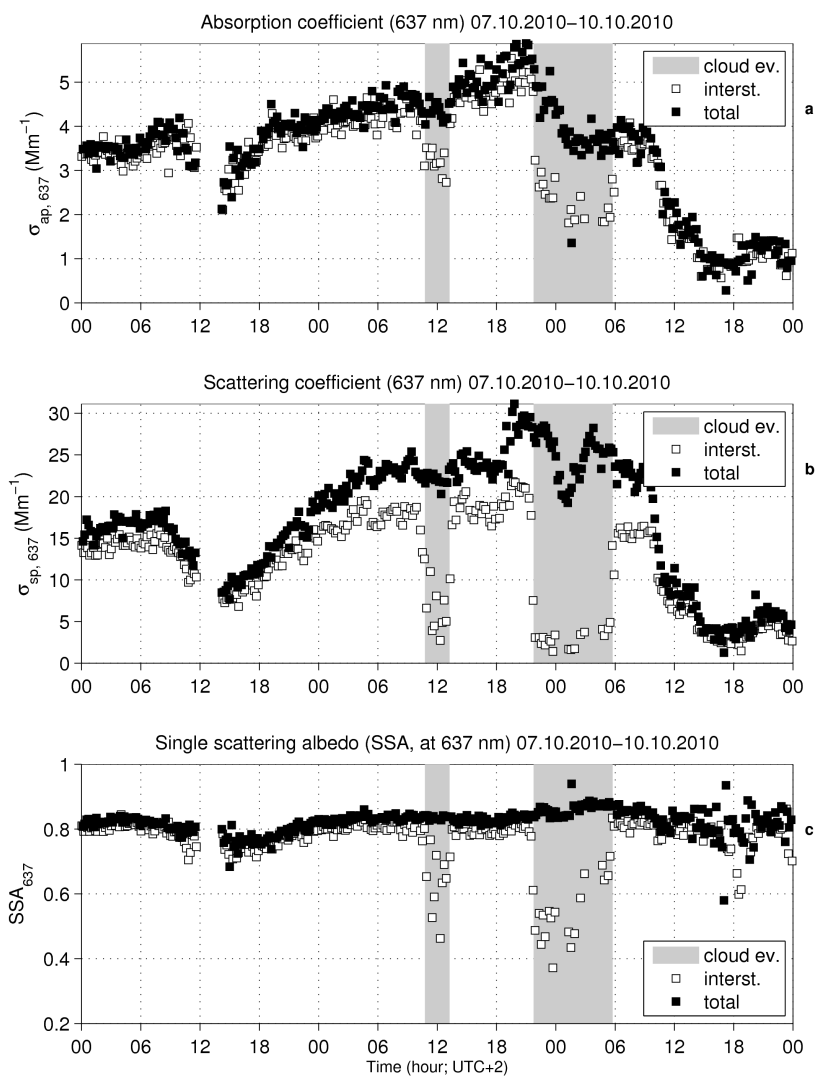

Fig. 10. The (a) total scattering coefficient at $637 \mathrm{~nm}$, (b) absorption coefficient at $637 \mathrm{~nm}$, and (c) single scattering albedo at $637 \mathrm{~nm}$ ( $\left.\mathrm{SSA}_{637}\right)$ of total and interstitial (interst.) aerosol particles at Puijo 7-11 October 2010, when two cloud events (cloud ev.) took place.

the second cloud event, respectively. This results in an approximately $20 \%$ decrease in the SSA. A similar drop in the SSA from $\sim 1$ to 0.8 was observed by Berkowitz et al. (2011) in a foggy situation. The scavenging is less efficient during the first cloud event when there are local, fresher emissions mixed in the sampled air. This is in line with the conclusion by Sellegri et al. (2003) that aging enhances scavenging of carbonaceous aerosols in clouds.

During the 4-year period, there were altogether 260 cloud events, resulting in $1082 \mathrm{~h}$ of in-cloud data. These low-level cloud events occurred mainly in the autumn and early winter (Portin et al., 2009), when the relative humidity was at its highest (Fig. 2b). The analysis of all the cloud events will be done in a separate paper.

\section{Summary and conclusions}

We examined aerosol optical properties at a semi-urban measurement station, $230 \mathrm{~m}$ above the surroundings, in an observation tower at Puijo in Kuopio, Finland, by measuring light scattering and absorption by aerosol particles with a threewavelenght nephelometer and a multi-angle absorption pho- tometer, respectively. By interpreting a four-year data set we were able to determine the annual and diurnal variation of the aerosol scattering and absorption coefficients, single scattering albedo, scattering Ångström exponent and the diurnal cycle of hemispheric backscattering fraction. When we inspected these parameters and results from aerosol mass spectrometry as a function of wind direction, we could see the effect of local sources (a paper mill, traffic, and residential areas) on the aerosol optical and chemical properties. We compared the measured parameters to those obtained at Arctic sites and nearby measurement stations, and concluded that Puijo can be regarded as a relatively clean site, regarding the aerosol optical properties. As a case study, we examined how the scattering and absorption coefficient were affected by cloud events.

In our earlier study (Leskinen et al., 2009) we found that when the wind blows from the northeast, where the paper mill resides, the sulphur dioxide concentration is elevated. In this study we found that also the sulphate concentration in aerosol particles is higher for the NE sector than for the other directions. We conclude that the increase in the scattering coefficient and single scattering albedo results from the sulphate-rich aerosol from the paper mill, since aerosols containing sulphate are known to be good scatterers of light.

When the wind blows from the sectors with traffic and small scale wood combustion, the absorption coefficient and organic concentration increases, while single scattering albedo decreases. We conclude that the air masses from these sectors contained fresh, sooty and organics-rich aerosol from traffic and from small scale biomass combustion in residential biomass-fired appliances. The Ångström exponent was larger in the direction of the city center than the residential areas, suggesting that the aerosols emitted by traffic are smaller in size than those in the residential emissions. We conclude that in the wintertime the effect of emissions from the residential areas on absorption is stronger than that from the traffic, because the morning and afternoon peaks in the absorption coefficient, seen in the summertime, were masked by the more absorbing aerosols from the residential areas.

We observed an increase in the single scattering albedo when the wind blew from the northwesterly sector with less local sources. From this direction the Angström exponent was low indicating larger aerosol particles. Furthermore, the aerosol mass spectrometry revealed that in this direction there are more oxygenated organic aerosols in the air mass. According to the trajectory analysis, most of the air masses with northwesterly wind directions originate from the Arctic region. Therefore, we conclude that the increase in the SSA arises from the presence of long-range transported aerosol, which are known to be larger in size and more oxygenated than the fresh emissions.

We found that during a cloud event both the interstitial and total aerosol values for scattering and absorption coefficients decreased, and that the effect is stronger for the scattering (a $90 \%$ decrease) than for the absorption (a $30 \%$ decrease). 
What happens to the aerosol optical properties during a cloud event when the air masses come from different directions with different local sources, is under a more detailed inspection. Also, more aerosol mass spectrometry data will be analyzed in order to strengthen our knowledge about the role of the chemical composition of the aerosol particles in their activation into cloud droplets.

Acknowledgements. The authors acknowledge the financial support for instrumentation by the European Regional Development Fund (ERDF). The authors are very grateful for the technical support of A. Aarva, T. Anttila, A. Halm, H. Kärki, A. Poikonen and K. Ropa from FMI's Observation Services.

Edited by: E. Weingartner

\section{References}

Aaltonen, V., Lihavainen, H., Kerminen, V.-M., Komppula, M., Hatakka, J., Eneroth, K., Kulmala, M., and Viisanen, Y.: Measurements of optical properties of atmospheric aerosols in Northern Finland, Atmos. Chem. Phys., 6, 1155-1164, doi:10.5194/acp-6-1155-2006, 2006.

Aiken, A. C., DeCarlo, P. F., Kroll, J. H., Worsnop, D. R., Huffman, J. A., Docherty, K. S., ulbrich, I. M., Mohr, C., Kimmel, J. R., Sueper, D., Sun, Y., Zhang, Q., Trimborn, A., Northway, M., Ziemann, P. J., Canagaratna, M. R., Onasch, T. B., Alfarra, R., Prevot, A. S. H., Dommen, J., Duplissy, J., Metzger, A., Baltensperger, U., and Jimenez, J. L.: O/C and OM/OC ratios of primary, secondary, and ambient organic aerosols with highresolution time-of-flight mass spectrometry, Environ. Sci. Technol., 42, 4478-4485, 2008.

Anderson, T. L. and Ogren, J. A.: Determining aerosol radiative properties using the TSI 3563 integrating nephelometer, Aerosol Sci. Technol., 29, 57-69, 1998.

Anderson, T. L., Covert, D. S., Marshall, S. F., Laucks, M. L., Charlson, R. J., Waggoner, A. P., Ogren, J. A., Caldow, R., Holm, R. L., Quant, F. R., Sem, G. J., Wiedensohler, A., Ahlquist, N. A., and Bates, T. S.: Performance characteristics of a high-sensitivity, three-wavelength, total scatter/backscatter nephelometer, J. Atmos. Ocean. Technol., 13, 967-986, 1996.

Andrews, E., Ogren, J. A., Bonasoni, P., Marinoni, A., Cuevas, E., Rodriguez, S., Sun, J. Y., Jaffe, D. A., Fischer, E. V., Baltensperger, U., Weingartner, E., Collaud Coen, M., Sharma, S., Macdonald, A. M., Leaitch, W. R., Lin, N.-H., Laj, P., Arsov, T., Kalapov, I., Jefferson, A., and Sheridan, P.: Climatology of aerosol radiative properties in the free troposphere, Atmos. Res., 102, 365-393, 2011.

Ansmann, A., Riebesell M., and Weitkamp C.: Measurements of atmospheric aerosol extinction profiles with a Raman lidar, Opt. Lett., 15, 746-748, 1990.

Arnott, W. P., Moosmüller, H., Rogers, C. F., Jin, T., and Bruch, R.: Photoacoustic spectrometer for measuring light absorption by aerosol: instrument description, Atmos. Environ., 33, 28452852, 1999.

Barriopedro, D., Fischer, E. M., Luterbacher, J., Trigo, R. T., and García-Herrera, R.: The hot summer of 2010: redrawing the temperature record map of Europe, Science, 332, 220-224, doi:10.1126/science.1201224, 2011.

Baynard, T., Lovejoy, E. R., Petterson, A., Brown, S. S., Lack, D., Osthoff, H., Massoli, P., Ciciora, S., Dube, W. P., and Ravishankara, A. R.: Design and application of a pulsed cavity ringdown aerosol extinction spectrometer for field measurements, Aerosol Sci. Technol., 41, 447-462, 2007.

Berkowitz, C. M., Berg, L. K., Yu, X.-Y., Alexander, M. L., Laskin, A., Zaveri, R. A., Jobson, B. T., Andrews, E., and Ogren, J. A.: The influence of fog and airmass history on aerosol optical, physical and chemical properties at Pt. Reyes National Seashore, Atmos. Environ., 45, 2559-2568, 2011.

Bodhaine, B. A.: Aerosol measurements at four background sites, J. Geophys. Res., 88, 10753-10768, 1983.

Bodhaine, B. A.: Aerosol absorption measurements at Barrow, Mauna Loa and the south pole, J. Geophys. Res., 100, 89678975, 1995.

Bohren, C. F. and Huffman, D. R. (Eds.): Absorption and scattering of light by small particles, John Wiley, New York, USA, 1983.

Bond, T. C., Anderson, T. L., and Campbell, D.: Calibration and intercomparison of filter-based measurements of visible light absorption by aerosols, Aerosol Sci. Technol., 30, 582-600, 1999.

Bond, T. C., Covert, D. S., and Müller, T.: Truncation and angularscattering corrections for absorbing aerosol in the TSI 3563 nephelometer, Aerosol Sci. Technol., 43, 866-871, 2009.

Chen, G., Ziemba, L. D., Chu, D. A., Thornhill, K. L., Schuster, G. L., Winstead, E. L., Diskin, G. S., Ferrare, R. A., Burton, S. P., Ismail, S., Kooi, S. A., Omar, A. H., Slusher, D. L., Kleb, M. M., Reid, J. S., Twohy, C. H., Zhang, H., and Anderson, B. E.: Observations of Saharan dust microphysical and optical properties from the Eastern Atlantic during NAMMA airborne field campaign, Atmos. Chem. Phys., 11, 723-740, doi:10.5194/acp11-723-2011, 2011.

Collaud Coen, M., Weingartner, E., Furger, M., Nyeki, S., Prévôt, A. S. H., Steinbacher, M., and Baltensperger, U.: Aerosol climatology and planetary boundary influence at the Jungfraujoch analyzed by synoptic weather types, Atmos. Chem. Phys., 11, 5931-5944, doi:10.5194/acp-11-5931-2011, 2011.

Delene, D. J. and Ogren, J. A.: Variability of aerosol optical properties at four North American surface monitoring sites, J. Atmos. Sci., 59, 1135-1150, 2002.

Fierz-Schmidhauser, R., Zieger, P., Wehrle, G., Jefferson, A., Ogren, J. A., Baltensperger, U., and Weingartner, E.: Measurement of relative humidity dependent light scattering of aerosols, Atmos. Meas. Tech., 3, 39-50, doi:10.5194/amt-3-392010, 2010.

Fischer, E. V., Jaffe, D. A., Marley, N. A., Gaffney, J. S., and Marchany-Rivera, A.: Optical properties of aged Asian aerosols observed over the U.S. Pacific Northwest, J. Geophys. Res., 115, D20209, doi:10.1029/2010JD013943, 2010.

Heintzenberg, J. and Charlson, R. J.: Design and applications of the integrating nephelometer: a review, J. Atmos. Ocean. Technol., 13, 987-1000, 1996.

Hyvärinen, A.-P., Lihavainen, H., Komppula, M., Sharma, V. P., Kerminen, V.-M., Panwar, T. S., and Viisanen, Y.: Continuous measurements of optical properties of atmospheric aerosols in Mukteshwar, northern India, J. Geophys. Res., 114, D08207, doi:10.1029/2008JD011489, 2009. 
Hänel, G.: Vertical profiles of the scattering coefficient of dry atmospheric particles over Europe normalized to air at standard temperature and pressure, Atmos. Environ., 32, 1743-1755, 1998.

IPCC (Intergovernmental Panel on Climate Change), Climate Change 2007 - The Physical Science Basis, edited by: Solomon, S., Cambridge Univ. Press, New York, 2007.

Jayne, J., Leard, D., Zhang, X., Davidovits, P., Smith, K., Kolb, C., and Worsnop, D.: Development of an aerosol mass spectrometer for size and composition analysis of submicron particles, Aerosol Sci. Technol., 22, 49-70, 2000.

Klett, J. D.: Stable analytical inversion solution for processing lidar returns, Appl. Opt., 20, 211-220, 1981.

Knox, A., Evans, G. J., Brook, J. R., Yao, X., Jeong, C.-H., Godri, K. J., Sabaliauskas, K., and Slowik, J. G.: Mass absorption crosssection of ambient black carbon aerosol in relation to chemical age, Aerosol Sci. Technol., 43, 522-532, 2009.

Leskinen, A., Portin, H., Komppula, M., Miettinen, P., Arola, A., Lihavainen, H., Hatakka, J., Laaksonen, A., Lehtinen, K. E. J.: Overview of the research activities and results at Puijo semiurban measurement station, Boreal Env. Res., 14, 576-590, 2009.

Müller, T., Henzing, J. S., de Leeuw, G., Wiedensohler, A., Alastuey, A., Angelov, H., Bizjak, M., Collaud Coen, M., Engström, J. E., Gruening, C., Hillamo, R., Hoffer, A., Imre, K., Ivanow, P., Jennings, G., Sun, J. Y., Kalivitis, N., Karlsson, H., Komppula, M., Laj, P., Li, S.-M., Lunder, C., Marinoni, A., Martins dos Santos, S., Moerman, M., Nowak, A., Ogren, J. A., Petzold, A., Pichon, J. M., Rodriquez, S., Sharma, S., Sheridan, P. J., Teinilä, K., Tuch, T., Viana, M., Virkkula, A., Weingartner, E., Wilhelm, R., and Wang, Y. Q.: Characterization and intercomparison of aerosol absorption photometers: result of two intercomparison workshops, Atmos. Meas. Tech., 4, 245-268, doi:10.5194/amt-4-245-2011, 2011.

Pandolfi, M., Cusack, M., Alastuey, A., and Querol, X.: Variability of aerosol optical properties in the Western Mediterranean Basin, Atmos. Chem. Phys., 11, 8189-8203, doi:10.5194/acp-11-81892011, 2011.

Petzold, A. and Schönlinner, M.: Multi-angle absorption photometry - a new method for the measurement of aerosol light absorption and atmospheric black carbon, J. Aerosol Sci., 35, 421-441, 2004.

Portin, H. J., Komppula, M., Leskinen, A. P., Romakkaniemi, S., Laaksonen, A., and Lehtinen, K. E. J.: Observations of aerosolcloud interactions at the Puijo semi-urban measurement station, Boreal Env. Res., 14, 641-653, 2009.
Portin, H., Mielonen, T., Leskinen, A., Arola, A., Pärjälä, E., Romakkaniemi, S., Laaksonen, A., Lehtinen, K. E. J., and Komppula, M.: Biomass burning aerosols observed in Eastern Finland during the Russian wildfires in summer 2010 - Part 1: in situ aerosol characterization, Atmos. Environ., 47, 269-278, 2012.

Seinfeld, J. H. and Pandis, S. N.: Atmospheric chemistry and physics: from air pollution to climate change, Second Edition, Wiley-Interscience, New York, USA, 2006.

Sellegri, K., Laj, P., Dupuy, R., Legrand, M., Preunkert, S., and Putaud, J.-P.: Size-dependent scavenging efficiencies of multicomponent atmospheric aerosols in clouds, J. Geophys. Res., 108, D11, 4334, doi:10.1029/2002JD002749, 2003.

Shinozuka, Y., Redemann, J., Livingston, J. M., Russell, P. B., Clarke, A. D., Howell, S. G., Freitag, S., O’Neill, N. T., Reid, E. A., Johnson, R., Ramachandran, S., McNaughton, C. S., Kapustin, V. N., Brekhovskikh, V., Holben, B. N., and McArthur, L. J. B.: Airborne observation of aerosol optical depth during ARCTAS: vertical profiles, inter-comparison and fine-mode fraction, Atmos. Chem. Phys., 11, 3673-3688, doi:10.5194/acp-11-36732011, 2011.

Shiraiwa, M., Kondo, Y., Iwamoto, T., and Kita, K.: Amplification of light absorption of black carbon by organic coating, Aerosol Sci. Technol., 44, 46-54, 2010.

Stohl, A., Wotawa, G., Seibert, P., and Kromp-Kolb, H.: Interpolation errors in wind fields as a function of spatial and temporal resolution and their impact on different types of kinematic trajectories, J. Appl. Meteorol., 34, 2149-2165, 1995.

Virkkula, A., Backman, J., Aalto, P. P., Hulkkonen, M., Riuttanen, L., Nieminen, T., dal Maso, M., Sogacheva, L., de Leeuw, G., and Kulmala, M.: Seasonal cycle, size dependencies, and source analyses of aerosol optical properties at the SMEAR II measurement station in Hyytiälä, Finland, Atmos. Chem. Phys., 11, 4445-4468, doi:10.5194/acp-11-4445-2011, 2011.

Weingartner, E., Nyeki, S., and Baltensperger, U.: Seasonal and diurnal variation of aerosol size distributions $(10<D<750 \mathrm{~nm})$ at a high-alpine site (Jungfraujoch $3580 \mathrm{~m}$ a.s.1.), J. Geophys. Res., 104, 26809-26820, 1999.

Zieger, P., Fierz-Schmidhauser, R., Gysel, M., Ström, J., Henne, S., Yttri, K. E., Baltensperger, U., and Weingartner, E.: Effects of relative humidity on aerosol light scattering in the Arctic, Atmos. Chem. Phys., 10, 3875-3890, doi:10.5194/acp-10-38752010, 2010. 